\title{
Gender Fairness in National Pensions
}

\author{
John W. Goodell, The University of Akron, USA
}

\section{Gender Fairness and Pensions}

The intersection of international business (IB) research and public policy is a relatively new and growing area of interest. Public policy can affect the behavior of private firms, and, in turn, firms can impact public policy; so, shaping social outcomes. Further, issues raised by IB-focused public policy research can provide very important context for private managers, even if such research does not yield one-size-fits-all answers - or it uncovers issues difficult to solve.

This short article suggests a relationship between gender fairness, national fiscal challenges, and pension design. The particular focus is on how the degree of connectedness of pension benefits to earnings history impacts both gender fairness and fiscal sustainability. In a world where there is a varying, but economically meaningful, gender wage gap across countries, disconnecting pension benefits from earnings history has the potential to provide both greater gender fairness and greater fiscal sustainability. However, as firms design private benefits to optimally offer utility in tandem with national pensions, private firms can be expected to compensate by increasing the connections of their benefits to earnings history. The net result is a potential dampening of benefits to gender development as a result of pension design changes.

\section{Three Pillars of Pension Design}

In order to consider the intertwining of gender fairness and pension design it is helpful to overview the World Bank's concept of three pillars. As private savings and public pensions are generally substituting, the design of public pensions influences the comparative utility of private benefits. This is because public and private-sector pensions, along with individual voluntary savings, mutually support each other. As first suggested by the World Bank, national pension systems can be categorized into a three-pillar grouping: (1) a non-contributory basic pension; (2) forced retirement savings; and (3) voluntary retirement savings. Often the first pillar performs an important social service as it protects the elderly from being forced to live below a minimum consumption level, while pillars 2 and 3 generally protect against a post-retirement decline in consumption. The second pillar usually provides benefits dependent on the level of contribution only to those that have contributed. The three pillars support each other, compensating for each other's weakness, and borrowing from each other's strengths. From this perspective, research into the factors that shape the design of public pensions is critical to informing those that design private-sector benefits. And, as discussed further below, when national pensions are redesigned to have greater gender fairness, other pension pillars will be expected to change and adapt to form a new three-pillar support structure.

\section{Public Pensions and Fiscall Stress}

Additionally, there is also a potentially favorable relationship in pension design between gender fairness and fiscal restraint. Given the great difficulty that many societies are facing, this can lead directly or indirectly to incentivizing changes to national pensions that further gender fairness. I discuss this further below in this article. But first, it is relevant to briefly note the fiscal difficulties nations are facing with regard to national pensions.

Currently, most developed economies, as a result of declining birth rates and increasing life expectancies, face significant demographic changes in the form of increases in the proportion of older people. Those retired must be supported in part by taxes on working adults, as individual retirement savings are often insufficient. Given projected demographic changes, pension-system reforms are accelerating as developed countries seek to forestall rising fiscal burdens (Lindbeck \& Persson, 2003).

In reforming their pension systems, however, countries have followed different paths. While some countries put more weight on superannuation systems that pay pension rates independent of a retiree's earnings history, other countries rely more on earnings-related benefits. The latter helps maintain 
retirement consumption levels that reflect some proportion of pre-retirement income. The former seeks a simple path toward retirees not being wards of the state. This degree of so-called progressivity varies across countries. However, it is possible that fiscal austerity and gender fairness in pension design are not necessarily tradeoffs as discussed in the next section.

\section{Public Pensions: Progressivity and Gender Fairness}

The degree of association of pension benefits with earnings history is an important feature of pension design. This quality of pension design, a measure of its redistribution, is known as pension progressivity. Pension progressivity regards more specifically the degree that pension benefits are determined by an individual's earnings history. A $100 \%$ progressive national pension would have no connection to earnings history and would be the same for all citizens of a respective country. ${ }^{1}$ This measure varies widely from a pension progressivity score of 100 for countries such as New Zealand, where national pension distributions are the same for all citizens, to scores close to zero for countries such as the Netherlands where there is wide inequali- ty of national pension distributions (due to an association with earnings history). To illustrate, the pension progressivity of select countries is shown in Figure 1.

Concomitantly, pension progressivity is closely linked with issues of gender fairness and gender development. Pension progressivity relates to gender issues because women generally have lower lifetime earnings. There is a disadvantage to women of pensions with a large earnings-related component since women generally earn less because of the physical burden of child bearing (St. John \& Willmore, 2001), as well as gender wage gaps. Therefore, if pensions are not progressive, and rather indexed to earnings history, women will necessarily have lower pensions. Consequently, some advocate for more progressive pensions because they are seen as providing a gender-equal distribution of tax dollars that do not disadvantage women for having lower lifetime earnings (e.g., Ginn, Street \& Arber, 2001; St. John \& Willmore, 2001; Schmall, 2002). Schmall (2002) notes the poor economic security of women as they age under pension systems which distribute benefits based on historical individual earnings. This problem is compounded by the higher life expectancies of women. Schmall (2002) suggests that women will be more favorably disposed toward government involvement in pensions because of self interest in resolving these income

Table 1. Pension Progressivity

\begin{tabular}{|l|c|l|c|}
\hline Country & Progressivity index & \multicolumn{1}{|c|}{ Country } & Progressivity index \\
\hline Ireland & 100.0 & Austria & 27.5 \\
\hline New Zealand & 100.0 & Argentina & 26.4 \\
\hline South Africa & 100 & Estonia & 25.6 \\
\hline Canada & 92.1 & Germany & 24.7 \\
\hline United Kingdom & 85.4 & China & 24.1 \\
\hline Israel & 79.5 & Spain & 23.8 \\
\hline Australia & 71.9 & Russian Federation & 21.1 \\
\hline Korea & 71.5 & Luxembourg & 16.6 \\
\hline Switzerland & 66.9 & Iceland & 13.9 \\
\hline Czech Republic & 62.2 & Slovak Republic & 4.0 \\
\hline Belgium & 60.6 & Finland & 3.9 \\
\hline Denmark & 57.0 & Netherlands & 3.5 \\
\hline Slovenia & 50.7 & Turkey & 1.4 \\
\hline Mexico & 47.4 & Italy & 0.9 \\
\hline Japan & 46.9 & Poland & 0.0 \\
\hline Norway & 45.3 & Hungary & 0.0 \\
\hline United States & 42.6 & Indonesia & 0.0 \\
\hline Greece & 39.0 & Saudi Arabia & -0.8 \\
\hline India & 32.6 & Portugal & -2.0 \\
\hline France & 30.6 & Brazil & -13.1 \\
\hline Chile & 27.9 & Sweden & \\
\hline
\end{tabular}

Source: 2013 OECD Earnings Distribution Database 
inequalities, whereas for similar reasons men will be more inclined to view government involvement in pensions negatively as a source of higher taxes.

Questioning the fairness toward women of earnings-based pension systems, Ginn et al. (2001) suggest that flat-rate pensions are potentially a good way to reduce the impact of the child-caring role of women on pension income. O'Rand and Henretta (1999) note that wage inequality is highly correlated with pension inequality, while Lazear and Rosen (1987) posit that inequality in lifetime earnings is highly correlated with pension inequality. As women across the globe typically receive lower wages and work fewer total hours, women will receive less pension benefits from earnings-based pension systems. As women live relatively longer than men, the gender disadvantage toward women of associating pension income with earnings history will be exacerbated.

Of course, whether pensions ought to be connected to earnings history, or not, is controversial. As noted by, for instance, Valdes-Prieto (2000), disconnecting pensions to earnings history might be seen as disincentivizing work contribution or encouraging moral hazard with regard to individual retirement investments. Others might advocate for progressive pensions because they are generally less fiscally costly. Indeed, pension design, and reform and retrenchment is typically highly politicized (Anderson, 2001).

\section{Progressive Pensions: Gender Fair- ness and Lower Cost?}

Net replacement regarding pensions has to do with how much of your pre-retirement levels of consumption are preserved by the pension plan. More progressive pensions consistently have much lower net replacement. Why? The answer has to do with examining, from a public financing perspective, what the goals are of differing public-pensions designs. Is the goal to help citizens preserve pre-retirement levels of consumption? If so, there must be a connection of pension benefits to earnings as earnings determines consumption prior to retirement. Also, such a pension must have a higher replacement rate and must be more fiscally burdensome because preserving pre-retirement consumption is much more fiscally expensive than simply what it would cost to keep retirees from being a burden to the state.

On the other hand, progressive pensions such as in New Zealand where everyone post 65 years of age receives annually one third the national average wage allows the government of New Zealand to inexpensively keep retirees off the street. There is nothing inherent to prevent societies from having progressive pensions with high replacement rates. It just wouldn't make sense. And populations would not be expected to support high universal pension benefits. ${ }^{2}$
In sum, because progressive pensions are fiscally affordable, gender fairness and fiscal sustainability are likely complements rather than substitutes.

\section{Progressive Pensions toward Reducing the Gender Pay Gap: A Caltch-22?}

It might appear, therefore, that progressive public pensions are an ideal combination of fiscal affordability and gender fairness. However, in the presence of a gender pay gap, gender differences in pension wealth will be somewhat more challenging to address. This is because, in the presence of progressive public pensions, earnings-related private pensions will correspondingly become more valuable. The three pillars will adjust to each other. The more progressive the public pension, the more valuable to workers will be earnings-related private pensions in order to preserve pre-retirement levels of consumption beyond minimum sustainment.

Clearly, private firms are in a very different position than national governments to address gender equity in pensions. It is difficult to envision a private firm offering flat pensions unrelated to work salaries, with the offering of pensions often seen as a way of attracting employees.

Further, public pensions can be supported, as in New Zealand for instance, by nation-wide taxation. Private pensions, on the other hand, are naturally linked to worker contributions. Consequently, if there is a gender wage gap, there will be a gender gap in pension replacements as well. Additionally, since private and public pensions are in some measure substituting pillars, the more a national pension is a flat progressive system, the more private nonprogressive pensions will be valued by employees. Indeed, firms should be cognizant that, up to a point, private pension systems will provide more utility to workers when the respective national system is more progressive. This is for two reasons: 1) flat pensions have low replacement rates and so are unsatisfactory vehicles on their own to preserve pre-retirement higher levels of consumption; and 2) those that are working will naturally value having benefits associated with work history. At the end of the day, there is a challenge to policy makers to address gender equity in pensions: more progressive national pensions will encourage substitution with nonprogressive private pensions that have replacement rates that reflect gender pay gaps.

And so, while the world may well be turning to flat pensions to improve fiscal balances, this will likely not be a complete answer to assuaging of inequities created by gender pay gaps and gender differences in lifetime earnings. But this is not an entirely inescapable conundrum in all contexts. In environments of particularly high gender pay gaps, progressive pension 
systems appear to make sense, particularly for nations where progressivity is lacking in other vital respects.

The USA comes to mind in this regard. Its public pension system, Social Security, is strongly tied to earnings, with private benefits, including health care, tied to private employment. Additionally, in the USA, the cost of university education, the vehicle to gain better employment, and so better pension benefits, is also high. The institutional structure of the USA is particularly vulnerable to a gender pay gap amplifying through the pension system. In this regard, it is interesting to reflect on the current fringe candidacy for the US presidency of Andrew Yang. The widely observed focus of his campaign is an advocacy of a universal wage of $\$ 1000$ per month for all US citizens. This seemingly radical suggestion, that few would think could or would be ever implemented, is to some degree analogous to taking a slightly more generous payout to that of the New Zealand superannuation and extending it considerably downward from a 65-years-old cut-off to being applicable to all adults. An extreme policy notion, but perhaps not so crazy when compared to progressive national pension systems already implemented in a number of countries.

At the end of the day, progressive pensions may be less effective to mitigate gender pay gaps and gender differences in lifetime earnings than might at first appear, because of the substitutability of private pensions. However, flat pensions make sense in environments of high gender pay gaps and other forms of inequality, or in environments where there are significant intertwinements of benefits and employment. Alternatively, in environments of less inequality, or where there are institutions of progressive public benefits, private earnings-associated benefits will likely be more valued by current or potential employees.

\section{References}

Anderson, K. M. 2001. The politics of retrenchment in a social democratic welfare state: reform of Swedish pensions and unemployment insurance. Comparative Political Studies, 34(9): 1063-1091.

Farhi, E., \& Panageas, S. 2007. Saving and investing for early retirement: A theoretical analysis. Journal of Financial Economics, 83(1): 87-121.

Feldstein, M. 1998. A new era of Social Security. Public Interest, 130(Winter): 102-125.

Ginn, J., Street, D. \& Arber, S. 2001. Women's pension outlook: variations among liberal welfare states. In J. Ginn, D. Street, \& S. Arber (Eds), Women, Work and Pensions: International Issues and Prospects. Buckingham, UK: Open University Press.

Lazear, E. P., \& Rosen, S. 1987. Pension Inequality. In Z. Bodie, J. B. Shoven, \& D. A. Wise (Eds), Issues in Pension Economics. Chicago: University of Chicago.
Lindbeck, A., \& Persson, M. 2003. The gains from pension reform. Journal of Economic Literature, 41 (1): 74-112.

O'Rand, A. M., \& Henretta, J. C. 1999. Age and Inequality: Diverse Pathways Through Later Life. Boulder, CO: Westview Press.

Schmall, L. A., 2002. Women and pension reform: Economic insecurity and old age. John Marshall Law Review, 35(4): 673-708.

St. John, S., \& Willmore, L. 2001. Two legs are better than three: New Zealand as a model for old age pensions. World Development, 29(8): 1291-1305.

Valdes-Prieto, S. 2000. The financial stability of notional account pensions. The Scandinavian Journal of Economics, 102(3): 395-417. Willmore, L. 2000. Three pillars of pensions? A proposal to end mandatory contributions. United Nations DESA Working Paper No. 13.

\section{Endinotes}

1 Sometimes this measure alternatively considers the relative egalitarianism of national pension distributions (including mandatory private systems) to the egalitarianism of earnings.

2 Willmore (2000) posits that this view is fundamentally regressive as any movement of federally allocated funds for pension away from flat pensions will go to finance benefits that go beyond simple minimum adequacy, i.e., to fund higher post-retirement consumption of the relatively wealthier taxpayers. On the other hand, Feldstein (1998) asserts that the safety net of a minimum pension encourages neglect of retirement saving. Public pension design certainly influences private savings rates (Farhi and Panageas, 2007).

John W. Goodell (Johngoo@uakron.edu) is an Associate Professor in the Department of Finance at The University of Akron. His research has focused the impact of culture, asymmetric information, and uncertainty on financial systems. He received his Ph.D. in 2008 from Kent State University. He is formerly Assistant Editor of Journal of Teaching in International Business (Taylor \& Francis) and is currently Editor-in-Chief of Elsevier's Research in International Business and Finance. 